\title{
Floristic Diversity of Karwapani Wetland of Doon Valley, Uttarakhand,India
}

\author{
${ }^{1}$ Nisha Subba, ${ }^{2}$ Pramod Kumar and ${ }^{3}$ Laxmi Rawat \\ ${ }^{1}$ Forest Ecology and Environment Division \\ ${ }^{2,3}$ Forest Research Institute, Dehradun.
}

\begin{abstract}
Karwapani swamp forest is situated near Manak Sidh temple nearby Shimla road and is about 15 $\mathrm{Km}$ north of Dehra Dun occupying an area of about 3-4 Sq Km. It forms the typical habitat, where water oozes out at places known as 'Oogals' which form perennial streams. The floristic diversity study revealed that total 60 plant species belonging to 41 families were recorded in the study area. Out of this, 11 tree, 26 shrub and 23 herb species have been recorded respectively. The present status of Karwapani wetland forest states that it is under threat which needs to be investigated and conserved through proper and sustainable management practices.
\end{abstract}

(Key words: Karwapani wetland, floristic diversity, Oogals)

\section{Introduction}

Wetland is a generic term used to define the universe of wet habitats including marshes, swamps, bogs, fens and similar area. Such land has water present at or near the surface for significant period that affect the land use. Wetlands are therefore subject to permanent or periodic inundation or prolonged soil saturation sufficient for the establishment of hydrophytic or the development of hydric soil. Recently, wetland has also been recognized for their role in recharge of aquifers and ground water, reduction in sediments load, control of flood, regulation of water quality, production of organic material, dependence of agriculture, animal husbandry and over water supply for drinking purposes in drought prone areas as well as save on wild habitat and reserved areas for conservation of endangered species. Plants and soils in wetlands play a significant role in purifying water. High levels of nutrients such as phosphorous and nitrogen, commonly associated with agricultural runoff, are effectively removed by wetlands. This is important in preventing eutrophication further downstream, a process that leads to rapid plant and algal growth followed by depleted oxygen levels that affect other species. It can also be important in preventing high concentrations of these nutrients reaching groundwater supplies or other water sources that may be used for drinking water (IUCN, 1971). In India many workers have carried out various works on vegetation of swamps (Kanjilal, 1901; Sen, 1959; Dakshini, 1960a, 1960b, 1961, 1965, 1970, and 1974; Som Deva and Aswal, 1974; Som Deva and Srivastava, 1978; Kaul et al., 1983; Kumar and Nandwani, 2003) but the floristic diversity of Karwapani wetland, which is under serious threats, needs to be studied, as meager work on floristic, ecological and socio-economy of this wetland is available. The present paper deals with the floristic diversity of Karwapani wetland in Doon Valley.

\section{Study site}

Doon Valley situated between the foot hills of the Himalayas and the Shiwaliks, is one of the most beautiful valleys of North India. There are a number of wetlands in the region, the most common are fresh water swamps of Doon Valley included Doodpani, Golatappar, Gularghati, Laltappar, Manu swamp, Mothronwala, Nakraunda, Ramgrah and Karwapani. Karwapani swamp forest is situated near Manak Sidh temple nearby Shimla road and is about $15 \mathrm{Km}$ north of Dehra Dun occupying an area of about 3-4 Sq Km. The swamp is surrounded by several villages, which include Buddhi, Nayagoan, Ganeshpur, Rattanpur and Pelio. It lies in the latitude $30^{\circ} 2^{\prime \prime}$ to $30^{\circ} 26^{\prime \prime}(\mathrm{N})$ and Longitude $77^{\circ} 52^{\prime \prime}$ to $78^{\circ}-19^{\prime \prime}(\mathrm{E})$. Mean maximum temperature is $19.2^{\circ} \mathrm{C}$ to $36.6^{\circ} \mathrm{C}$ and Mean minimum temperature is about $6.3^{\circ} \mathrm{C}$ to $23.2^{\circ} \mathrm{C}$. The Annual rainfall is $2015 \mathrm{~mm}$. The climate of the area is more or less like that of Dehra Dun being more temperate and humid than adjoining areas. Karwapani fresh water swamp is selected for the present study. It forms the typical habitat, where water oozes out at places known as 'Oogals' which form perennial streams.

\section{Materials and methods}

The study was conducted during the year 2010. For this purpose the method of nested quadrats $10 \mathrm{~m} \mathrm{x}$ $10 \mathrm{~m}$ for trees, $3 \mathrm{~m} \mathrm{x} 3 \mathrm{~m}$ for shrubs and $1 \mathrm{~m} \mathrm{x} 1 \mathrm{~m}$ for herbs were laid out using the quadrat method of Mishra (1968) and for this random sampling method were used. The plant species were collected and identified with the help of subject matter specialists and using flora of Kanjilal and Gupta (1969), Babu (1977) and R.D. Gaur (1999) to examine the description of the plants. 


\section{Result and Discussion}

The study revealed that total 60 plant species belonging to 41 families were recorded (Table 1). The dominant tree in area is Shorea robusta associated with a number of other trees and shrubs which are Syzygium cerasoide, Syzygium cumini, Mallotus phillippensis, Clerodendrum viscosum, Clerodendrum infortunatum, Ardisia solanacea, Colebrookia oppositifolia, Eupatorium adenophorum, Lantana camara. The herbaceous layer which dominated the area is Ageratum conyzoides, Cyanodon dactylon, Cyperus rotundus, Euphorbia hirta, Desmodium microphyllum, Ophlismenus composites, Smilax glaucaophylla, and Cissampelos pareira. Though Shorea robusta belonging to the family Dipterocarpaceae dominates the upper storey, the family which has the largest number of species are Combretaceae with 2 tree species, Ehretiaceae and Myrtaceae with two each .In middle storey the family Verbenaceae with 3 species dominates the area followed by Asteraceae, Fabaceae, Lamiaceae, Liliaceae, Myrtaceae and Solanaceae with 2 species each whereas in under storey Fabaceae and Euphorbiaceae with 3 species each dominated the study area.

\section{Discussion}

Species such as Cynodon spp, Cyperus spp and Euphorbia spp were found abundant in the present study. Cynodon and Cyperus on account of their abundance in the waterlogged sites in present investigation need to be considered as marshy species adhering to the definition of wetland/marsh (Cowardin et al. 1979). Earlier it was not included in the list of aquatic and marshy plants of Indian habitats (Lavania et al. 1990). Based on the reports of Rai and Sharma (1991) and Sharma et al. (2001) Euphorbia sp. was also considered as wetland species in the present study. The plant diversity of Karwapani swamp forest is represented by 53 families, 130 genera and 155 species (Dhyani and Joshi, 2007).A total of 162 plant species were found in Nakraunda swamp forest (Manhas et al.,2009).It is seen that the plant species which have been found from various parts of swamps in Doon Valley are not very uniform. The floristic diversity of Karwapani is very much less as compared to Nakraunda swamp (Manhas et al., 2009) and the previous study made in Karwapani (Dhyani and Joshi, 2007). High percentage of herbs and shrubs dominating the area indicates that the area is being disturbed by anthropogenic activities. According to the study made by Sharma and Joshi (2008) in Mothronwala swamp and Manhas et al. (2009) on fresh water swamp of Doon Valley, it has been reported that the dominance of shrubs and herbs in an area is caused by various high rate of anthropogenic disturbances. The possible reason for less floristic diversity may be due to various anthropogenic activities such as grazing, collection of fuel wood, fodder, food, medicinal plants etc. The present status of Karwapani wetland forest states that it is under threat which needs to be investigated and conserved through proper and sustainable management practices.

Table 1

\begin{tabular}{|c|c|c|}
\hline S.N & Botanical Name & Family \\
\hline \multicolumn{3}{|c|}{ Tree } \\
\hline 1 & Cordia obliqua, Willd. & Ehretiaceae \\
\hline 2 & Ehretia Laevis Roxb. & Ehretiaceae \\
\hline 3 & Litsea chinensis, Lamk. & Lauraceae \\
\hline 4 & Mallotus philippensis, Muell. & Euphorbiaceae \\
\hline 5 & Salix tetrasperma, Roxb. & Salicaceae \\
\hline 6 & Sapium sebiferum, Roxb. & Euphorbiaceae \\
\hline 7 & Shorea robusta, Gaertn.f. & Dipterocarpaceae \\
\hline 8 & Syzygium cerasoide, Roxb. & Myrtaceae \\
\hline 9 & Syzygium cumini, (Linn.) Skeels. & Myrtaceae \\
\hline 10 & Terminalia alata, Heyne. & Combretaceae \\
\hline 11 & Terminalia chebula, Retz. & Combretaceae \\
\hline \multicolumn{3}{|c|}{ Shrubs } \\
\hline 12 & Adhatoda vasica, Nees. & Acanthaceae \\
\hline 13 & Ardisia solanacea (Poir.) Roxb. & Myrsinaceae \\
\hline 14 & Asparagus adsendens, Roxb. & Liliaceae \\
\hline 15 & Asparagus racemosus, Willd. & Liliaceae \\
\hline 16 & Bamboo spp. & Poaceae \\
\hline 17 & Butea monosperma (Lamk.) Taub. & Fabaceae \\
\hline 18 & Carissa opaca, stapf ex Haines & Apocynaceae \\
\hline 19 & Cissampelos pareira, Linn. & Menispermaceae \\
\hline 20 & Cleodendron viscosum, Vent. & Verbenaceae \\
\hline 21 & Clerodendrum infortunatum, Gaertn. & Verbenaceae \\
\hline 22 & Colebrookia oppositifolia, Smith. & Lamiaceae \\
\hline 23 & Cudrenia cochinchinensis (Sapling) & Moraceae \\
\hline 24 & Eupatorium adenophorum, Spreng. & Asteraceae \\
\hline 25 & Flemingia bracteata, Wight. & Fabaceae \\
\hline 26 & Lantana camara, Linn & Verbenaceae \\
\hline 27 & Litsea chinensis Lamk. & Lauraceae \\
\hline 28 & Litsea umbrosa Nees & Lauraceae \\
\hline
\end{tabular}




\begin{tabular}{|c|c|c|}
\hline 29 & Milletia extensa, Benth. & Leguminoceae \\
\hline 30 & Murraya koenigi, Spreng. & Rutaceae \\
\hline 31 & Pogostemon benghalense, Kuntze & Lamiaceae \\
\hline 32 & Pterospermum acerifolium, Willd. & Sterculiaceae \\
\hline 33 & Randia spinosa & Rubiaceae \\
\hline 34 & Sida cordifolia, Linn. & Malvaceae \\
\hline 35 & Solanum khasianum, Clarke. & Solanaceae \\
\hline 36 & Solanum nigrum, Linn & Solanaceae \\
\hline 37 & Toona ciliata Roemer. (Sapling) & Tiliaceae \\
\hline \multicolumn{3}{|c|}{ Herbs } \\
\hline 38 & Achyranthes aspera, Linn. & Acanthaceae \\
\hline 39 & Ageratum conyzoides, Linn. & Asteraceae \\
\hline 40 & Phyllanthus ninuri, Linn. & Euphorbiaceae \\
\hline 41 & Curculigo orchioides, Gaertn & Hypoxidaceae \\
\hline 42 & Cynodon dactylon, Linn. & Poaceae \\
\hline 43 & Cyperus rotundus, Linn. & Cyperaceae \\
\hline 44 & Desmodium microphyllum, DC. & Fabaceae \\
\hline 45 & Desmodium trifolium, DC. & Fabaceae \\
\hline 46 & Dioscorea hispida, Dennstaedt. & Dioscoreaceae \\
\hline 47 & Equisetum orintale & Equisitaceae \\
\hline 48 & Euphorbia hirta, Linn. & Euphorbiaceae \\
\hline 49 & Fragaria indica, Andrew. & Rosaceae \\
\hline 50 & Ichnocarpus frutescens, (Linn.) R.Br. & Apocynaceae \\
\hline 51 & Jasminum arborescens. Roxb & Oleaceae \\
\hline 52 & Oplismenus compositus, (Linn.) P. Beauv. & Poaceae \\
\hline 53 & Oxalis corniculata, Linn. & Oxalidaceae \\
\hline 54 & Phyllanthus ninuri Linn. & Euphorbiaceae \\
\hline 55 & Polygonum barbatum, Linn. & Polygonaceae \\
\hline 56 & Pteris quadriaurita, Retz & Pteridaceae \\
\hline 57 & Pteris villata, Linn. & Pteridaceae \\
\hline 58 & Smilax glaucophylla, Klotz & Smilacaceae \\
\hline 59 & Smilax zeylanica, Linn. & Smilacaceae \\
\hline 60 & Urena lobata, Linn. & Barringtoniaceae \\
\hline
\end{tabular}

\section{References}

[1]. Babu, C.R. (1977). Herbaceous Flora of DehraDun. Publication and Information Directorate, CSIR, New Delhi.

[2]. Cowardin, L.M., V. Carter, F.C. Golet and E.T. LaRoe.1979. Classification of Wetlands and Deep Water Habitats of the United States. U.S. Fish \& Wild Life Service Rep. FWS/OBS-79/31. US Govt. Printing Office, Washington D.C.

[3]. Dakshini, K.M.M. (1960a). The Vegetation of Mothronwala Swamp Forest. A preliminary survey. Bull, Botanical Survey of India, 9: 57-59.

[4]. Dakshini, K.M.M. (1965). A Study of the Vegetation of Mothronwala Swamp Forest, Dehra Dun, India. Jour.Indian Bot. Soc., 44: 411-428.

[5]. Dakshini, K.M.M. (1970). The flora of Mothronwala Swamp. J, Bom. Nat. Hist. Soc., 67: 176-186.

[6]. Dakshini, K.M.M. (1974). The flora of Mothronwala Swamp. J. Bom. Nat .Hist .Soc., 71(2): 235-243.

[7]. Dhyani, S. and Joshi, S.P. (2007). Angiospermic Diversity of Karwapani Fresh Water Swamp Forest in Doon Valley, Uttaranchal. Indian Forester. 1101-1108.

[8]. Gaur, R.D. (1999). Flora of District Garhwal North West Himalaya. Transmedia, Srinagar (Garhwal), U.P. India.

[9]. IUCN, (1971). The Ramsar Conference: Final act of the international conference and the conservation of wetlands and waterfowl. Special Supplement, IUCN Bull. 2(19): 1-4.

[10]. Kanjilal, U.N. (1901). Swamp forests in DehraDun, N.W. Province Ind. For, 27:228-230.

[11]. Kanjilal,U. and Gupta, B.L. (1969). Forest Flora of Chakrata, Dehradun and Saharanpur Forest Divisions, Uttar Pradesh. Manager of Publicatios Delhi. Printed at FRI press, P.L.O. FRI\&C, Dehradun.

[12]. Kaul, O.N., Sharma, D.C. and Tandon,V.N. (1983). Biomass distribution and productivity in a poplar plantation. Indian Forester, 109(11):822-828.

[13]. Kumar.S. and Nandwani. D. (2003). Plant diversity of some wetlands of Doon Valley, Oriental enterprises, Dehra Dun.

[14]. Lavania, G.S., S.C. Paliwal and B. Gopal. 1990. Aquatic vegetation of the Indian subcontinent. pp. 29-78. In: B. Gopal (ed.) Ecology and Management of the Aquatic Vegetation of the Indian Subcontinent. Kluwer Acad. Publishers, Dordrecht

[15]. Manhas, R.K., Gautam, M.K. and Deepa Kumari, (2009). Plant Diversity of a Fresh Water Swamp of Doon Valley, India. Journal of American Science 2009: 5(1), 1-7.

[16]. Rai, D.N. \& U.P. Sharma. (1991). Phyto-coenological structure and classification of wetlands in North- Bihar. pp. 111-116. In: B. Gopal \& V. Asthana (eds.) Aquatic Sciences in India. Indian Association for Limnology and Oceanography, New Delhi.

[17]. Sharma, K.P., Chaturvedi R.K., Sharma Kamayani and Bhardwaj,S.M. (2001). Dominance and diversity studies of vegetation of polluted habitats around Sanganer, Jaipur. Tropical Ecology 42(1): 69-82, 2001.

[18]. Sharma, Neelam and Joshi, S.P. (2008). Comparative study of Fresh water Swamp of Doon Valley. The Journal of American Science, 4(1):44-52.

[19]. Som Deva and Aswal, B.S. (1974). Taxonomy and Ecology of Mothronwala Swamp. A reassessment. Indian Forester, 100 (1): 1219.

[20]. Somdeva and Srivastava, M.M. (1978). An ecological study of the vegetation of Golatapper swamp, Dehradun. Indian J. For., 1. 4453. 